\title{
Rock and palaeomagnetic evidence for the Plio-Pleistocene palaeoclimatic change recorded in Upper Rhine Graben sediments (Core Ludwigshafen-Parkinsel)
}

\section{Rolf ${ }^{1,{ }^{*}}$, U. Hambach ${ }^{2} \&$ M. Weidenfeller ${ }^{3}$}

1 Leibniz Institute for Applied Geosciences (GGA), Stilleweg 2, 30655 Hannover, Germany.

2 University of Bayreuth, Geosciences, Chair of Geomorphology, 94450 Bayreuth, Germany.

3 Landesamt für Geologie und Bergbau Rheinland-Pfalz, Emy-Roeder-Str. 5, 55129 Mainz, Germany.

* Corresponding author. Email: christian.rolf@gga-hannover.de

Manuscript received: February 2005; accepted: August 2007

\begin{abstract}
This paper summarizes results of magnetostratigraphic and rock magnetic investigations performed on fluvial sediments from the LudwigshafenParkinsel drilling project (Upper Rhine Graben (URG) Germany). The drilling penetrated into Pleistocene gravel, sand, silt and clay, and unconsolidated Pliocene deposits. Its primary objective was the exploration of groundwater resources in the area of Ludwigshafen. Our rock magnetic investigations together with results of heavy mineral analyses (see Hagedorn \& Boenigk, 2008) show a clearly structured sediment profile. It was possible to identify the change from mainly locally controlled sedimentation from the Graben margins to a more distinct Alpine controlled sedimentation at a depth of $177 \mathrm{~m}$ by magnetic data. Based on lithostratigraphic correlation with other sedimentary records from the URG and also based on palynological evidence, this event happened at the end of Late Pliocene during a time of normal polarity of the Earth's magnetic field (Gauss Chron?). The well-documented characteristic change in magneto-mineralogy from goethite to greigite almost at the same stratigraphic level, we interpret solely as a climatic signal which can be correlated with the global climate change at $\sim 2.5 \mathrm{Ma}$ that is well documented in a wide range of sedimentary environments (e.g. deep-sea sediments, loess).
\end{abstract}

Keywords: magnetic polarity stratigraphy, environmental magnetism, fluvial sediments, Upper Rhine Graben, greigite, goethite

\section{Introduction}

One of the main problems in European Cenozoic stratigraphy is the lack of a well defined chronology of the dramatic climatic fluctuations in Late Pliocene and Quaternary terrestrial sedimentary sequences. Only a sound chronology allows for correlations of sedimentary archives from different environmental settings. Thus, a convincing chronology for the sedimentary records left by the glaciations north of the Alps is still missing (Becker-Hauman, 2001; Boenigk \& Frechen, 2005; Ellwanger et al., 2005; Strattner \& Rolf, 1995). In contrast to marine and lacustrine sediments or thick loess deposits, fluvial and glacial sediments are often exposed only in small sections or outcrops with almost undetectable sedimentary hiatuses. Therefore, it is often difficult to find the precise stratigraphic position of the profile under investigation. To overcome these difficulties, long sections recovered from drillings in sedimentary basins can be studied.

In the study presented here, we sampled a core which was recovered during the exploration for groundwater resources in the area of Ludwigshafen (Fig. 1). The cores from the drill hole Ludwigshafen-Parkinsel (P34) comprise $300 \mathrm{~m}$ of Quaternary and Tertiary sediments. A comprehensive geological and lithological description of the rocks drilled during that campaign can be found in Weidenfeller \& Kärcher (2008).

The here presented combined palaeo and rock magnetic investigations are restricted to selected silty to clayey core intervals (Fig. 2) because in contrast to sand and gravel finer grained sediments are generally good recorders of the Earth's magnetic field. The results of our palaeomagnetic investigations have to be regarded as preliminary. However, magnetic susceptibility was determined on the whole core at $0.5 \mathrm{~m}$ intervals. 


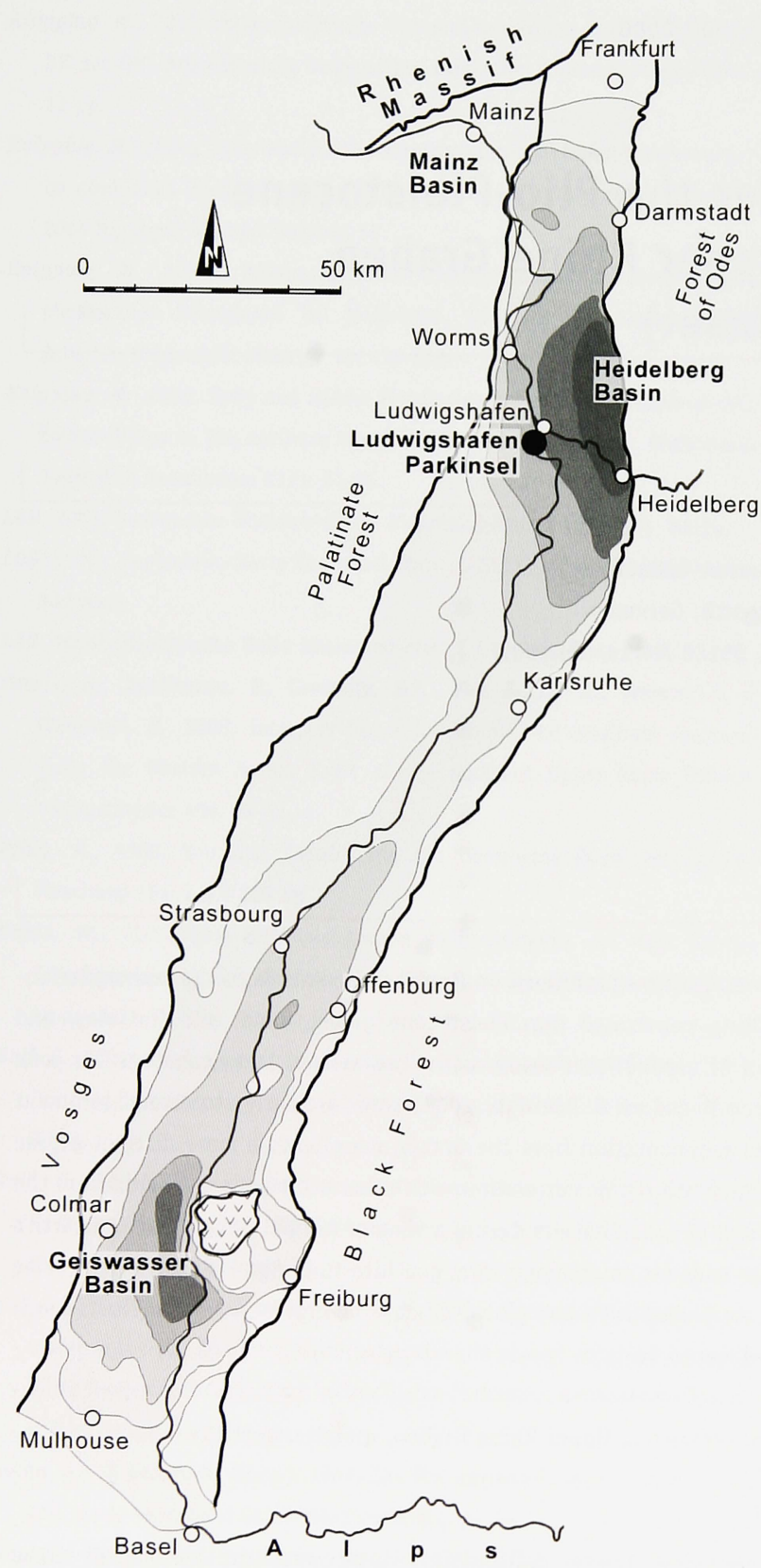

Fig. 1. Schematic map of the Upper Rhine Graben area (modified after Bartz, 1974) showing the drill site of Ludwigshafen Parkinsel (black dot) at the edge of the Heidelberg Basin.

\section{Methodological approach}

Ferromagnetic minerals (s.l.), which provide the magnetic signal, typically comprise less than a thousandth of the whole sample. Ferromagnetism is a general physical term and refers to crystalline solids with parallel coupling of adjacent atomic magnetic moments as antiferromagnetic, ferrimagnetic and ferromagnetic minerals. In contrast to paramagnetism, which refers to uncoupled atomic magnetic moments, the ferromagnetic effect is $10^{3}$ to $10^{4}$ times stronger. Thus, already very small traces of natural ferromagnetic minerals as iron-bearing oxides and sulphides rule the magnetisation of a rock. Moreover, they function as recorders of magnetic fields and provide therefore a memory of the temporal variations of the Earth's magnetic field from secular variation to polarity changes (cf. Butler, 1992).

In Plio-Pleistocene sedimentary sequences, magnetic polarity stratigraphy is an excellent and independent tool (as compared to oxygen isotope stratigraphy and orbital tuned cyclo-stratigraphy) for retrieving chronometric information. Magnetic polarity stratigraphy employs the temporal pattern of reversals of the Earth's magnetic field documented in the geomagnetic polarity timescale (GPTS). It is based on the polarity changes of the Earth's magnetic field as recorded in volcanic rocks or sediments.

In their seminal textbook entitled 'Environmental Magnetism' Thompson \& Oldfield (1986) established a new research field. Environmental changes not only concern the grain size distribution and bulk mineralogical composition of sediments but also affect their magnetic mineralogy. Variations in concentration, grain size, and composition of magnetic minerals characterize sediments by reflecting source rocks, catchments, transport mechanism, pathways, and diagenetic processes. Consequently, they are useful proxies for environmental changes.

Since the 1960's, a variety of different rock magnetic parameters and techniques have been developed which initially were used exclusively for mineral magnetic studies. Most of these techniques can be used easily, quickly and are non-destructive to the rock under investigation. The larger part of the instruments necessary for environmental (rock magnetic) investigations consist of standard equipment used in palaeomagnetic laboratories. Some of the rock magnetic proxies used in the present paper are described below:

1. The initial magnetic mass susceptibility $\left(\mathrm{K}\left(\mathrm{m}^{3} \mathrm{~kg}^{-1}\right)\right)$ is a bulk representation of ferromagnetic contents (plus paramagnetic component in weakly magnetized samples). It indicates changes in the concentration of magnetic minerals.

2. The so-called S-ratio gives us information about the relative amounts of high-coercivity ('hard') to low-coercivity ('soft') remanence and therefore a fair estimate of the importance of antiferromagnetics (goethite, hematite) versus ferrimagnetics (soft magnetite, iron-sulphides). The experiment to obtain S-ratio is to 'saturate' a sample in forward direction ('SIRM') and then expose it to backfield (e.g. 0.3 T). In the case of hard remanences a saturation of remanence very often is not possible with the fields available in our laboratory (max. 2.7 T). Hence, SIRM is written in brackets to demonstrate that sometimes remanence is far from saturation. Dividing the 'backfield'-remanence by 'SIRM' produces the S-ratio. Values close to unity mean that remanence is dominated by soft ferrimagnets, small values by hard ferrimagnets (Evans \& Heller, 2003). 


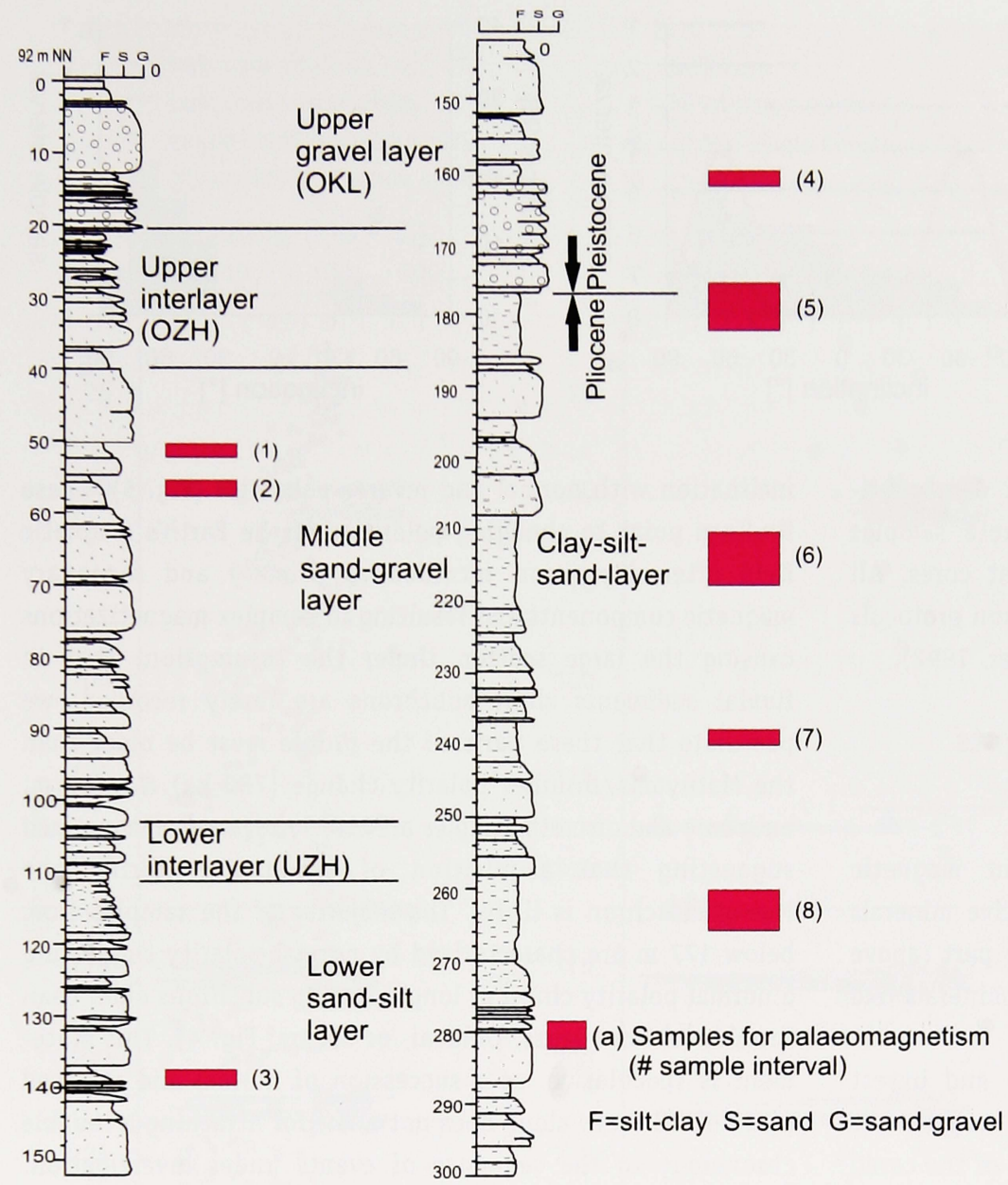

Fig. 2. Lithological structure along the profile of Parkinsel (P34) core modified after Weidenfeller \& Kärcher (2008). Rectangles mark core sections where palaeomagnetic investigations have been carried out. Size of boxes indicates investigated core intervals (sample intervals are given in brackets).
3. Anhysteretic remanent magnetization (ARM) is a widely used parameter in environmental magnetism and helps to identify the mineralogy and grain size of magnetic assemblages. ARM was produced by a constant biasing field of $0.1 \mathrm{mT}$ at the same time with a peak alternating demagnetization field of $100 \mathrm{mT}$. ARM is often compared with an isothermal remanent magnetization (IRM) created in a constant magnetic field of similar strength (100 mT). Both parameters are independent from dia-, para-, and superparamagnetic minerals. The dependency on grain size and concentration is for ARM well developed, whereas the dependency on coercivity is less in comparison to other magnetic parameters (Von Dobeneck, 1993).

\section{Sampling and further laboratory procedures}

In the middle and northern Upper Rhine Graben (URG), the sediments are commonly characterized by gravel-beds ('Kieslager'; KL) and intercalated fine grained horizons ('Zwischenhorizonte'; ZH) (Fig. 2). Gravel and sand do not record the Earth's magnetic field and therefore sampling for palaeomagnetic analysis concentrated on the fine-grained parts of the core. Firstly, the natural remanent magnetization of selected cores was measured using the long core cryogenic magnetometer at the magnetic laboratory of the GGA-Institute Hannover (Leibniz Institute for Applied Geosciences) at Grubenhagen near Einbeck (Rolf, 2000). Secondly, a susceptibility screening was performed using a multicore-logger provided by the BGR Hannover (Federal Institute for Geosciences and Natural Resources). In addition, discrete samples for susceptibility measurements were taken from the whole core in $0.5 \mathrm{~m}$ intervals and were measured in the laboratory for palaeo- and environmental magnetism at the Chair of Geomorphology, University of Bayreuth.

In the cores, only orientation with respect to the vertical axis is preserved. Thus, the inclination component of the natural remanent magnetization is used to infer polarity. In the case of primary-records of normal and reversed polarity the inclination must show a bimodal distribution around the expected dipole value for Ludwigshafen $\left(67^{\circ}\right.$ plus secular variation, positive for normal and negative for reverse). The bulk core measurements are often not well defined due to too weak magnetic signals caused by disturbances. Additionally, core edge problems can cause a smeared-out distribution with a maximum around the present dipole field (Fig. 3a). Further, secondary viscous (normal) remanence components mask the inverse directions in the lower part of the section (see next chapter). Therefore, the expected bimodal distribution could 
Fig. 3. Distribution of NRM inclination values for bulk core measurements (a) and discrete sample ChRM (b). A theoretical smooth curve for the expected bimodal distribution is drawn as a red line (a). The right abscissa refers to the sample intervals of Fig. 2.

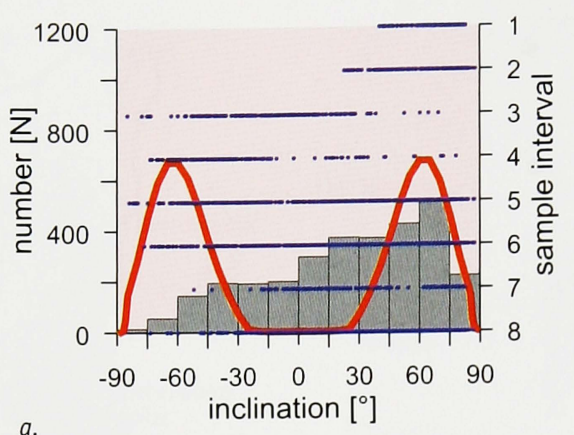

a.

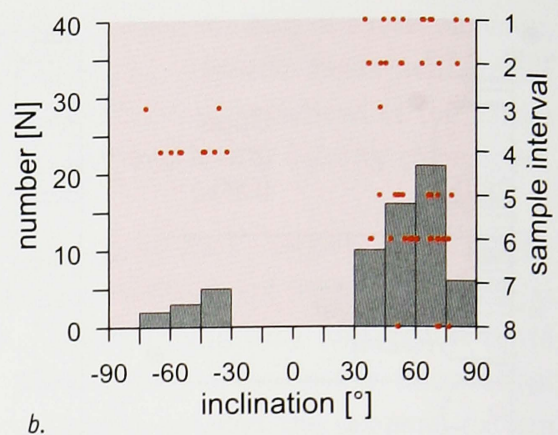

only be achieved by measuring and subsequent demagnetization. These experiments were done on discrete samples (2 $\mathrm{cm}$ edge length) prepared from the sediment cores. All samples were subjected to standard demagnetisation protocols (alternating field (AF) or thermal (TH)) (cf. Butler, 1992).

\section{Results of demagnetization experiments and magnetic polarity stratigraphy}

Demagnetization experiments revealed different magnetic minerals as carriers of magnetization. Low coercive minerals (magnetite or iron sulphide) dominate the upper part (above $177 \mathrm{~m}$ ), whereas in the lower part high coercive minerals like goethite or hematite prevail.

Highest mean intensity of NRM $(24 \mathrm{~mA} / \mathrm{m})$ and lowest scatter of direction (in the bandwidth of secular variation) is concentrated in the two upper sampling intervals of the cored sequence $(0-70 \mathrm{~m})$. Here only normal polarity is recorded indicating remanence acquisition during the Brunhes chron (Fig. 4). All other parts of the core show large scatter in

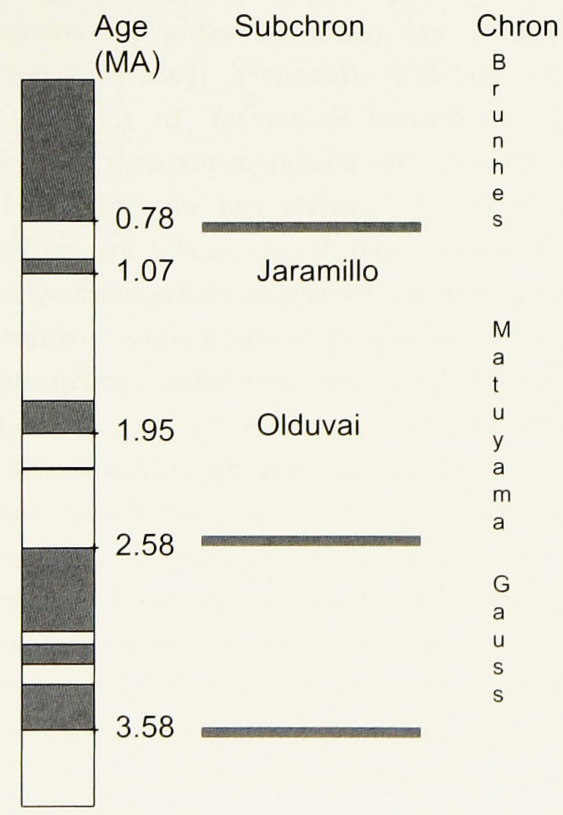

Fig. 4. Simplified Plio-Pleistocene geomagnetic polarity time scale adapted after Mankinen \& Dalrymple (1979) and Cande \& Kent (1995). inclination with normal and reverse polarities (Fig. 5). These findings point to changing polarities of the Earth's magnetic field after deposition recorded as primary and secondary magnetic components and resulting in complex magnetizations causing the large scatter. Under the assumption, that in fluvial sediments short subchrons are rarely recorded, we postulate that these parts of the profile must be older than the Matuyama/Brunhes polarity change (780 ka). At $160 \mathrm{~m}$, bulk core and discrete samples are clearly reversely magnetized suggesting that acquisition of remanence during the Matuyama chron is likely. The majority of the samples from below $177 \mathrm{~m}$ are characterized by normal polarity suggesting a normal polarity chron or longer lasting subchrons older than Brunhes chron (Gauss, Olduvai, or others; Fig. 4). This statement is speculative, as a succession of normal and reversed magnetized rocks alone does not allow for attaching a reliable chronology to the sequence of events under investigation. Without any further independent stratigraphic indication, the described magnetostratigraphic succession is only one of several alternative interpretations.

\section{Results of rock magnetic investigations and environmental magnetism}

Environmental magnetism is applied rock magnetism reflecting source rocks, catchments, transport mechanism, pathways and diagenetic processes. Our results from demagnetization experiments on discrete samples show low coercive minerals (magnetite or iron sulphide) dominating the upper part (above $177 \mathrm{~m}$ ) whereas in the lower part high coercive minerals like goethite or hematite dominate.

As shown by the core measurements, the natural remanent magnetization (NRM) correlates with magnetic susceptibility $\mathrm{K}$ (Fig. 5) indicating that remanence carrying minerals also control the environmental magnetic signal. The $\mathrm{K}$-mean of $10 \cdot 10^{-8} \mathrm{~m}^{3} / \mathrm{kg}$ for the studied intervals (K-max $30 \cdot 10^{-8} \mathrm{~m}^{3} / \mathrm{kg}$; $\mathrm{K}$-min $3 \cdot 10^{-8} \mathrm{~m}^{3} / \mathrm{kg}$ ) shows low scatter and typical values for clay and siltstones.

Discrete sampling (not oriented) with spacing of $0.5 \mathrm{~m}$ was performed to retrieve a more complete susceptibility profile. Before determination of susceptibility all samples were sieved using a $200 \mu \mathrm{m}$ sieve at the laboratory for rock magnetic 
a

bulk core intensity

- bulk core susceptibility

- single sample susceptibility

- Susceptibility discrete sampling

Susceptibility [ $\left.{ }^{\star} 10^{-6} \mathrm{SI}\right]$ b

bulk core

- NRM-single sample

- ChRM single sample (AF)

ChRM single sample (TH)

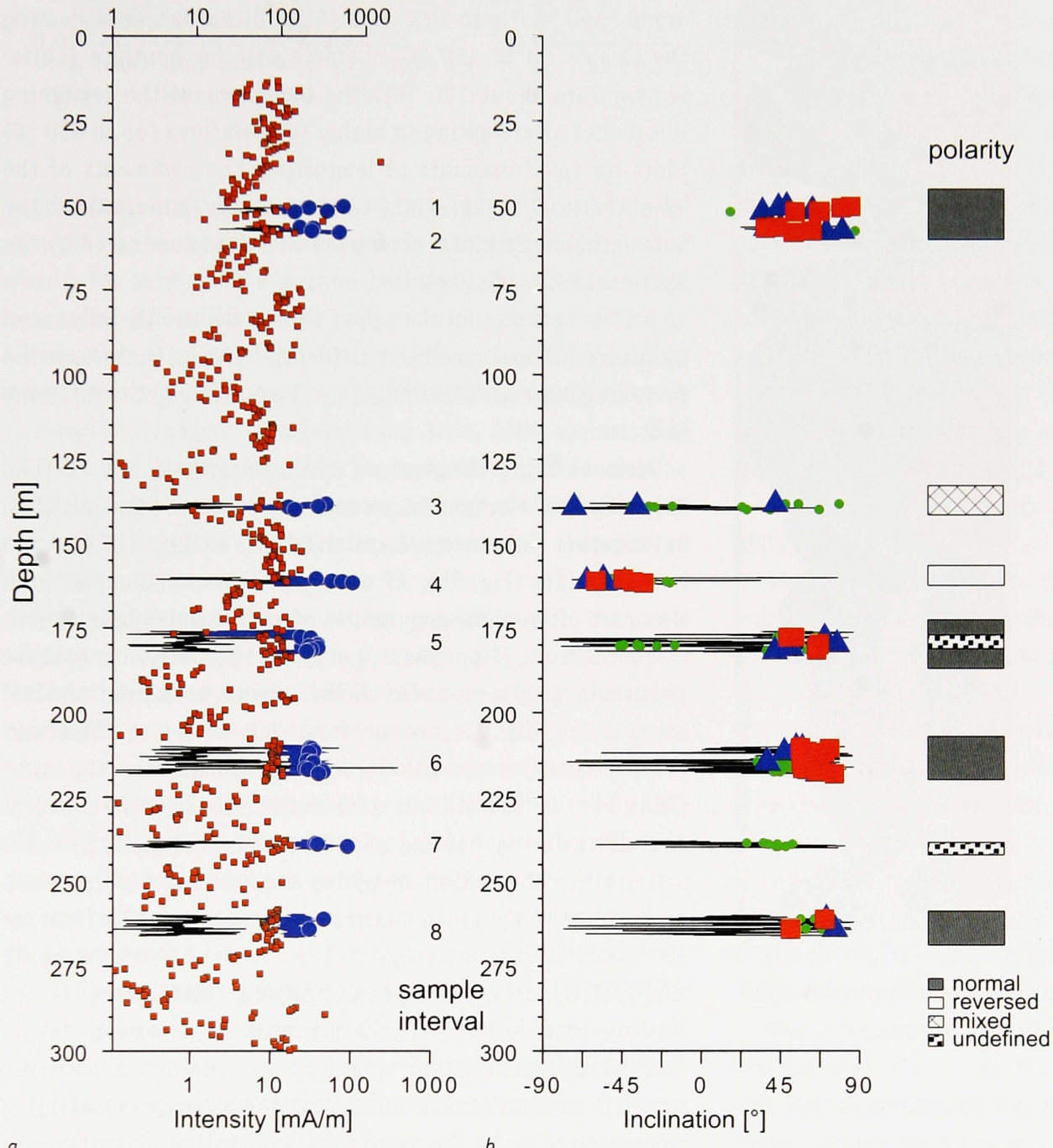

Fig. 5. Summary of rock magnetic bulk core and discrete sample data versus depth. a. Bulk core intensity (black line), susceptibility (blue line) and discrete sample susceptibility (small red squares); $b$. Inclination bulk core NRM (black line), discrete sample NRM (small green dots), discrete sample ChRM after AF demagnetization (blue triangles) and after $T H$ demagnetization (red squares) shown together with interpretation of polarity.

investigations of the University of Bayreuth (Chair of Geomorphology). Susceptibility measurements were performed on the fraction $<200 \mu \mathrm{m}$ and were normalized to the maximum values. The results of the susceptibility measurements are plotted as function of depth and shown in comparison with a heavy mineral analyses performed by Hagedorn (2004) (Fig. $6)$. For description of the heavy mineral analyses and their detailed results see Hagedorn \& Boenigk (2008).

As demonstrated in figure 6, a clear correlation of heavy mineral data and susceptibility data is apparent. Susceptibility from samples from the lower part (below $177 \mathrm{~m}$ ) is characterized by significant low values. The heavy mineral data from that same part are categorized by a mixed heavy mineral assemblage with unstable (garnet, hornblende and epidote) and stable (zircon, tourmaline, anatase) minerals. Following
Hagedorn and Boenigk this mineral assemblage results from the contribution of sediments derived from the Black Forest and the Vosges and transported to the north by the protoRhine. At this time, material eroded from the Graben margins dominated the geomorphic system. Above $177 \mathrm{~m}$, susceptibility increases remarkably in coincidence with a characteristic change in heavy mineral spectra. Here unstable minerals (garnet, epidote) prevail, representing sediments of Alpine provenance (Hagedorn, 2004). Interestingly these sediments show higher susceptibilities than sediments derived from the Graben margins. This pattern persists during repeated changes between Alpine-derived and locally derived sediments reflecting the changing course of the Rhine and the tectonic as well as the climatic control of sedimentation. 
norm. susceptibility

$\%$ of heavy minerals
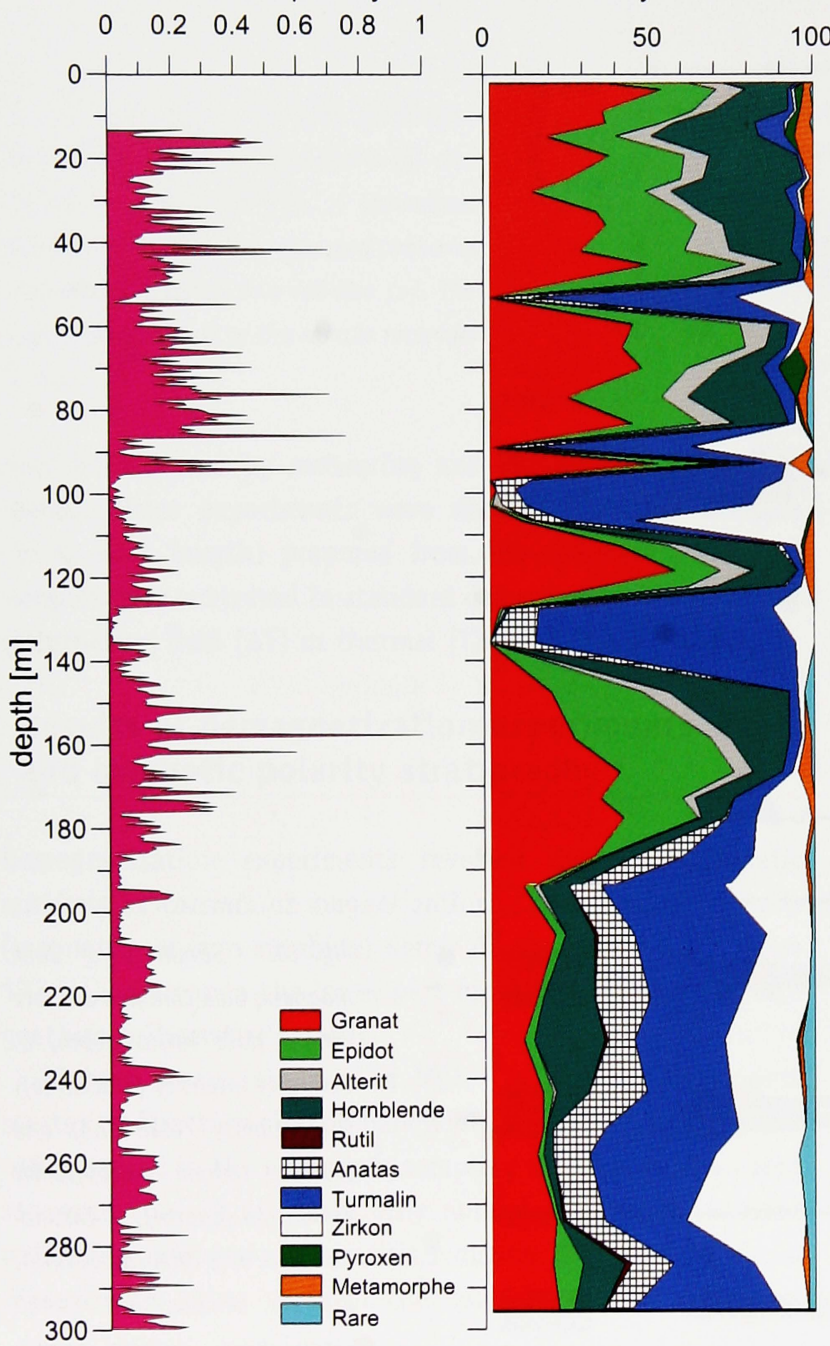

Fig. 6. Normalized susceptibility and heavy mineral data versus depth (after Hagedorn \& Boenigk, 2008).

Depth versus S-ratio (Fig. 7a) again demonstrates that the Ludwigshafen-Parkinsel profile can be divided into two parts: an upper soft and a lower hard magnetic part with the boundary line at $\sim 177 \mathrm{~m}$. This result is supported by 'saturation' IRM curves (Fig. $7 \mathrm{~b}, \mathrm{c}$ ) which also show a clear subdivision in soft (above $177 \mathrm{~m}$ ) and hard (below $177 \mathrm{~m}$ ) remanence carriers.
Thermal demagnetization of 'SIRM' helps to understand which hard and soft magnetic minerals prevail. In the case of hard magnetic minerals it is not possible to distinguish between hematite and goethite from the SIRM curve alone. As shown in Figure $8 \mathrm{a}$, samples from the lower part of the profile are characterized by a blocking temperature spectrum of the SIRM around $150{ }^{\circ} \mathrm{C}$. Up to $50 \%$ of the SIRM disappears after heating the sample up to $150{ }^{\circ} \mathrm{C}$, characteristic for goethite (Curietemperature about $120^{\circ} \mathrm{C}$ ). The behaviour of the remaining remanence after heating to higher temperatures (up to $630^{\circ} \mathrm{C}$ ) hints on small amounts of magnetite. The sediments of the lower part (without Alpine derived heavy minerals) of the Ludwigshafen Parkinsel profile are therefore dominated by the hydrous iron oxide goethite.

On the contrary, in the upper part of the profile influenced by Alpine mineral assemblages (depth $<177 \mathrm{~m}$ ) greigite is the prevailing mineral. This finding can be proofed by the following facts:

Main blocking temperature spectrum around $300{ }^{\circ} \mathrm{C}$ (Fig. $8 \mathrm{~b}$ ); scanning electron microscope of separated minerals (Fig. 9a) together with energy dispersive X-ray analysis (EDX) shows iron sulphides (Fig. 9b); AF demagnetization of samples from this part often show acquisition of significant gyroremanent magnetization (Fig. 10a), a typical property of greigite (Snowball, 1997); stepwise thermal demagnetization of SIRM using a modified technique from Van Velzen \& Zijderveld (1992) identifies greigite in stead of pyrrhotite (Fig. 10b) (Torii et al., 1996). This technique is based on chemical alteration during heating experiments, which is typical for greigite (decomposition in pyrite and marcasite at temperatures above $\sim 200^{\circ} \mathrm{C}$ ). In contrast to pyrrhotite which is stable up to its Curie point $\left(\sim 320^{\circ} \mathrm{C}\right)$. In case of pyrrhotite only thermal unblocking happens, bringing 'SIRM' back to its starting point after each thermal step. If, however, during thermal demagnetization of a 'SIRM' a decrease in magnetization is due to thermal unblocking and chemical alteration a remagnetization in the same field will restore magnetisation to a lower level because 'magnetisable' material has been irreversibly lost. This behaviour is typical for greigite (Evans \& Heller, 2003) and shown in Figure 10b.
Fig. 7. a. S-ratio versus depth; $b$. isothermal remanent magnetization (IRM) acquisition curve indicative for soft at $161.15 \mathrm{~m}$; and c. hard remanence carriers at $181.30 \mathrm{~m}$.

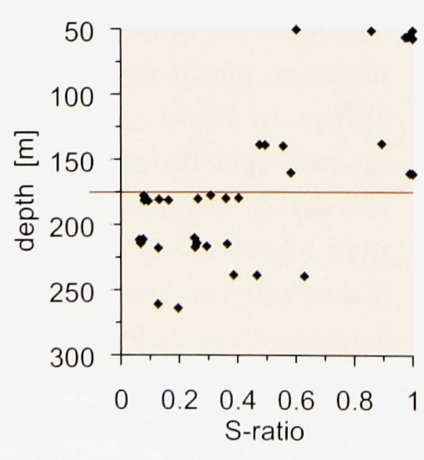

a.

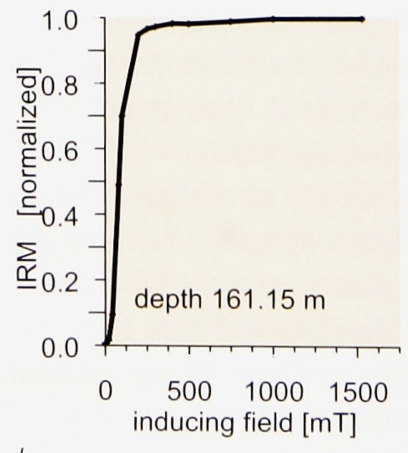

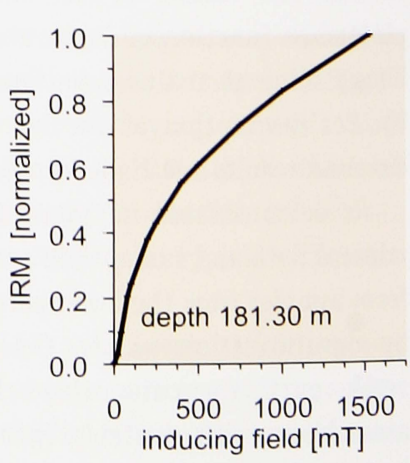




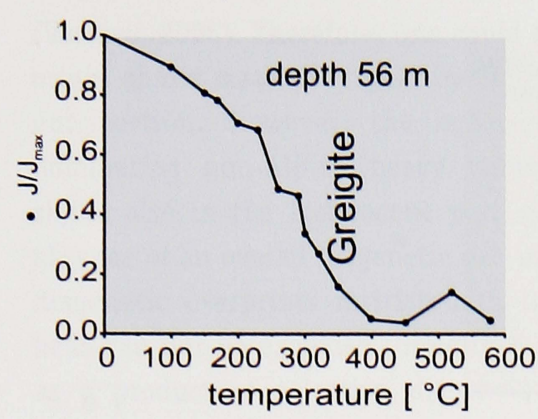

a.

Combination of different parameters in biplots can help to separate various magnetic components into distinct parameter spaces. We applied this method by combining ARM and IRM measurements in different ways. Concentration dependence of ARM is often eliminated by plotting ARM against IRM. A double logarithmic two-dimensional graph (as a third dimension depth of samples is added as colour code) from ARM against IRM (Fig. 11a) demonstrates high concentration differences for samples from the upper part (above $177 \mathrm{~m}$ ) of the profile and narrow plotting (low concentration variations) for samples of the lower part (below $177 \mathrm{~m}$ ).

This behaviour shows higher variation in magneto mineralogy of the upper part in comparison to the lower part. The relationship of ARM and IRM differs clearly for the lower and upper part of the sediment profile, as demonstrated by regression lines, pointing to different magneto mineralogical content. A similar plot, the relation of ARM normalized by IRM and ARM, emphasizes this result (Fig. 11b). Again, two different clusters (high coercivity mineral (goethite) in the lower and low coercivity mineral (greigite) in the upper part of the profile) are obvious (with the exception of some samples in a mixed zone). These few simple examples show that it is worthwhile to plot the results of individual parameters in several ways to retrieve qualitative identification of different groups of magnetic minerals present in the material under investigation.

\section{Discussion}

It is possible to divide at a depth of $\sim 177 \mathrm{~m}$ the LudwigshafenParkinsel succession into normal (below $177 \mathrm{~m}$ ) and reverse magnetized sequences as well as into sequences dominated by hard magnetic minerals (goethite) (below $177 \mathrm{~m}$ ) and soft magnetic minerals (greigite). Palynological investigations revealed a Tertiary pollen spectrum at depths greater than $177 \mathrm{~m}$, whereas for the upper part of the Ludwigshafen-Parkinsel succession different Pleistocene interglacial and interstadial periods could be identified (Knipping, 2004; Knipping, 2008). Furthermore there is some evidence that the change to more Alpine dominated sediments at $177 \mathrm{~m}$ occurs at the end of the Late Pliocene (Boenigk et al., 1974; Hagedorn \& Boenigk, 2008).

The chronostratigraphic Plio-Pleistocene boundary itself is still a matter of debate. There has been consensus that the boundary should be placed at the first evidence of climatic cooling of ice-age magnitude. This was the basis for placing the boundary in marine sediments in Calabria at 1.81 million years (Aguirre \& Pasini, 1985) and therefore into the normal polarized Olduvai subchron (e. g. Harland et al., 1990). At present there is no doubt that a major cooling occurred already earlier at 2.55 million years (cf. Litt et al., 2002). Thus, it is proposed by many researchers to move the boundary to the Gauss/Matuyama magnetic chron boundary (Suc et al., 1997; www.quaternary.stratigraphy.org.uk).

The interpretation of the polarity pattern determined on the Ludwigshafen-Parkinsel sediments argues for the older Plio-Pleistocene boundary, if we take the heavy mineral data as a clear marker for the base of the Quaternary. It is very unlikely that the nearly $100 \mathrm{~m}$ thick sediments below the petrographic change boundary with normal polarity represent the only 200000 years lasting Olduvai subchron (Cande \& Kent, 1995). On the other hand, our magnetostratigraphic results are dominated by gaps and uncertainties about the primary
Fig. 9. a. Scanning electron microscope of mineral separates shown together with $b$. energy dispersive $X$-ray analysis detecting iron ( $\mathrm{Fe}$ ) sulphur (S).
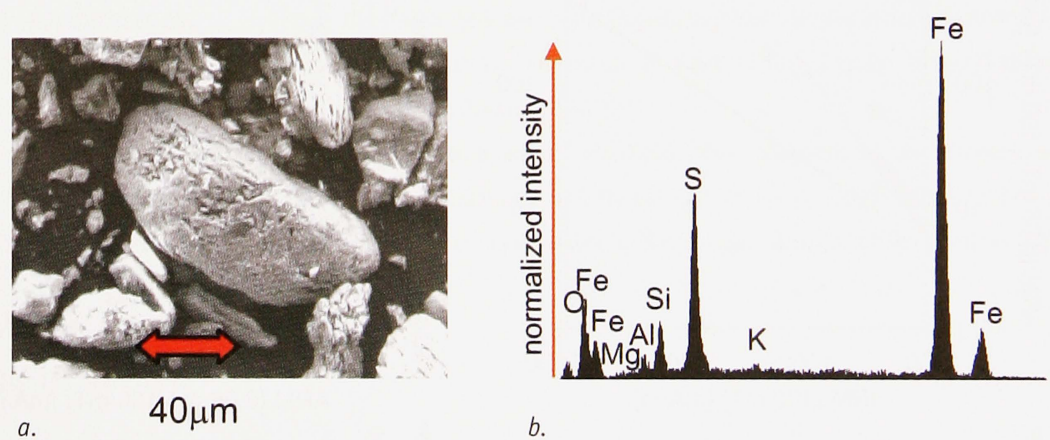

b. 

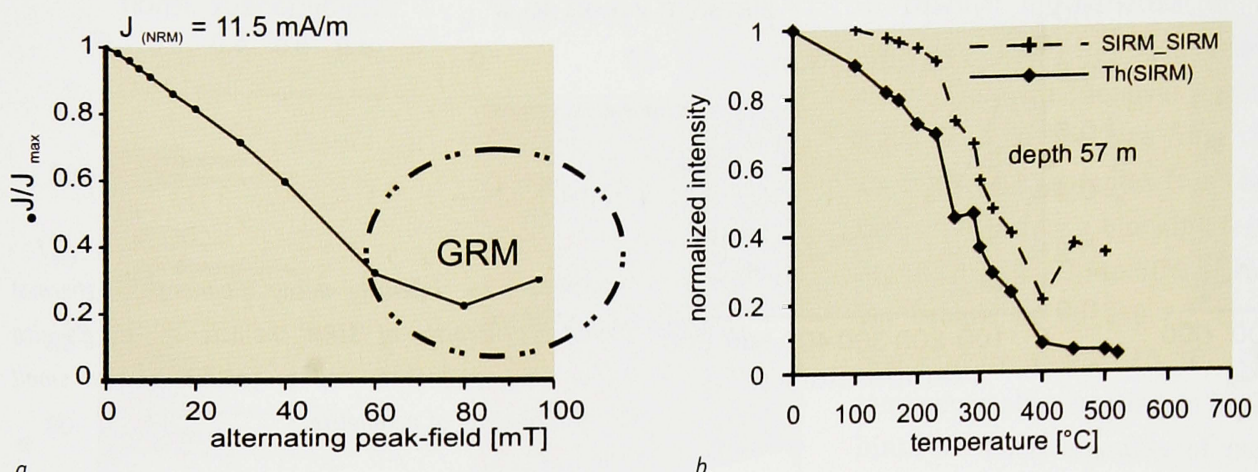

b.

Fig. 10. a. Normalized intensity decay diagram (left) for alternating field (AF) demagnetization showing gyromagnetic effects by increasing intensity for peak field values $>60 \mathrm{mT}$; b. Stepwise thermal demagnetization of 'SIRM' (diamond) against temperature. After each thermal step the sample was remagnetised in the 'SIRM' field (crosses). Due to chemical alteration remagnetised 'SIRM' only reaches lower level above $200^{\circ} \mathrm{C}$; this is typical for greigite in contrast to pyrrhotite (see text for detailed description).

character of the determined polarity pattern making an interpretation only based on our magnetostratigraphic results still speculative.

However, changes in heavy mineral data and the palynological findings coincide with the change from goethite to greigite as remanence carrying minerals at 177 meters. Goethite is a typical mineral of weathering and is the stable iron oxide in soils of humid climates (Thompson \& Oldfield, 1986). Greigite as an iron sulphide tends to be very unstable in air, one of the reasons for the relatively poor knowledge about the rock magnetic properties of greigite (Evans \& Heller, 2003). Greigite is an authigenic magnetic mineral (lacustrine and brackish water sediment) and plays an important role as carrier of remanence in palaeomagnetic investigations of Quaternary sediments. The presence of greigite in sedimentary sequences is only possible under distinct (anaerobe) conditions and can be used to identify palaeoenvironments favouring its formation (Snowball \& Torii, 1999).

The palaeoclimatic change at the Pliocene-Pleistocene boundary is reflected in the Upper Rhine Graben sediments firstly by the connection of the Alpine catchment to the drainage system of the Rhine (Hagedorn \& Boenigk, 2008), and secondly by a fundamental change in humidity. In the Pliocene, the sediments show generally brownish to yellowish colours whereas the Pleistocene sequences are greyish. The brownish to yellowish colours indicate oxidizing environments during deposition. Due to extensive seasonal drought, the groundwater table during deposition of the Pliocene floodplain sediments was lowered during summer leading to thorough oxidation. During the Pleistocene, however, the floodplain sediments were most probably almost all the year watersaturated which prevented widespread oxidation of iron minerals. Thus, in the Pleistocene sequences the detrital magnetic signal is preserved whereas in the Pliocene the sediments suffered intense oxidation.

Low to medium grade metamorphic rocks of the Helvetic and Penninic Nappes occur in the catchment of the Alpine Rhine. These rocks contain magnetite and pyrrhotite bearing schist's and are also an important source for the instable Alpine heavy mineral assemblages (Rochette, 1987; Hagedorn and Boenigk, 2008). Horng and Roberts (2006) demonstrated recently the important role of detrital pyrrhotite derived from exhumed metamorphic rocks exposed in orogenic belts as remanence carrying mineral.

Greigite is so far not known as detrital mineral, but well documented as carrier of early diagenetic remanences in high sedimentation rate settings where the rapid burial of organic matter leads to a completely anoxic diagenetic environment

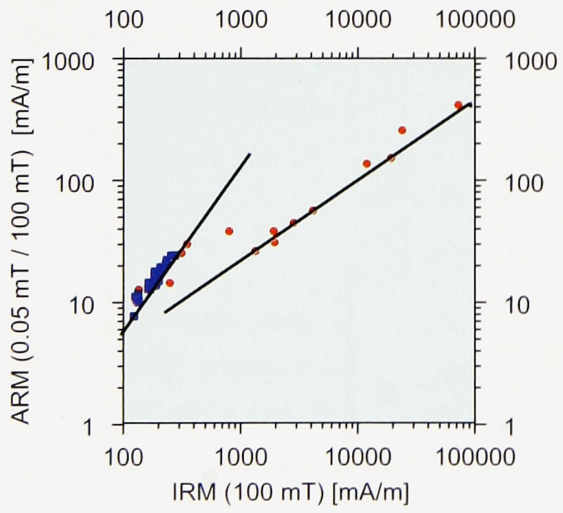

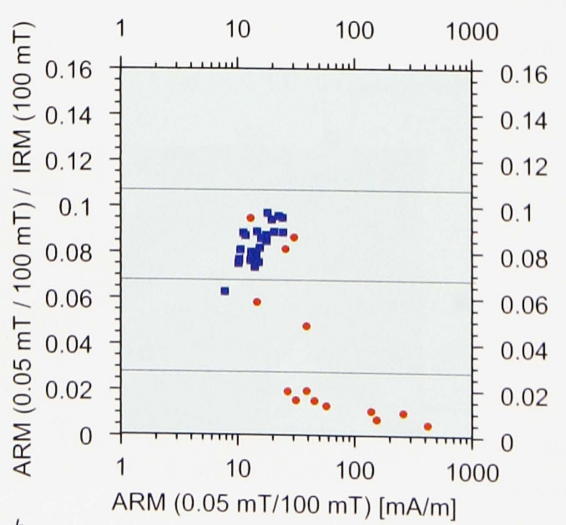

$b$.
Fig. 11. Room temperature biplots (samples from depth $<177 \mathrm{~m}$ are shown as red dots; samples from $>177 \mathrm{~m}$ are shown as blue squares): a. ARM versus IRM; b. ARM normalized by IRM versus ARM (see text for description). 
(Vasiliev, 2006). Therefore, one could argue for the diagenetic origin of the magnetic signal in the Pleistocene sediments of our section. However, the occurrence of intervals with dominating non-Alpine heavy minerals and low magnetic signal also in the Pleistocene part clearly demonstrates the absence of an overall diagenetic overprint. On the other hand, diagenetic overprints restricted to individual facies and/or beds can not be excluded. Greigite can therefore be regarded as a product of selective diagenetic alteration of detrital pyrrhotite or pyrite derived from the catchment of the Alpine Rhine. Rowan and Roberts (2006) found selective redoxprocesses affecting iron sulphides to be responsible for the magnetic characteristics of Neogene sediments from New Zealand which are dominated by Greigite. We believe that a similar process may be responsible for the magnetic properties of the Pleistocene sediments at Ludwigshafen-Parkinsel. However, further mineralogical and rock magnetic investigations are needed to confirm this hypothesis.

Based on these facts we postulate that the occurrence of goethite in the lower part of the Ludwigshafen-Parkinsel profile (Pliocene sediments) and the dominance of greigite in the upper part of the profile (Pleistocene sediments) is an important proxy for the environmental (climatic) change around 2.5 Ma. This worldwide climate change is marked by the initiation of the Northern Hemisphere glaciation and is well documented in deep-sea sediments (Shackleton et al., 1984), loess deposits in China (Heller \& Liu, 1982), fluviolacustrine sediments in central China (Han et al., 1997) and e.g. in changes of the Atlantic 0cean thermohaline circulation (Haug \& Tiedemann, 1998).

\section{Conclusions}

The magnetic investigations of core Ludwigshafen-Parkinsel have shown that:

Normal and reverse magnetized intervals can be identified. A change from hard magnetic minerals (goethite) to soft magnetic minerals (greigite) happens in sediments with normal polarity at a depth of $\sim 177 \mathrm{~m}$.

- Rock magnetic data reveal the dominance of goethite in the lower part $(>177 \mathrm{~m}$ ) and of greigite in the upper part of the profile.

- The goethite-dominated sediments are characterised by normal polarity, non-alpine heavy mineral assemblages, Tertiary pollen spectra and an overall oxidizing depositional environment.

- The greigite-dominated sediments go along with normal and reverse polarity, well defined Alpine heavy mineral assemblages, Pleistocene pollen spectra and an overall reducing depositional environment.

- This shift in magnetomineralogy at a depth of $\sim 177 \mathrm{~m}$ seems to be an important proxy for the global environmental (climatic) change at about 2.5 Ma.

\section{Acknowledgements}

We gratefully acknowledge Jim Rose, Wim Westerhoff and his colleague from TNO for their thorough revision of the manuscript. We are indebted to Dr Eva-Marie Hagedorn for allocation of heavy mineral data. The authors feel constrained to Dr Michael Wiedicke-Hombach from the Bundesanstalt für Geowissenschaften und Rohstoffe (BGR), Hannover, for the loan of the multi-core logger for susceptibility measurements on bulk cores. We like to thank Detlev Klosa from the Landesamt für Bergbau, Energie und Geologie (LBEG), Hannover for performance of scanning electron microscopy and EDX analyses as far as Kathrin Worm and Marianne Klick from the magnetic laboratory of the GGA-Institute, Hannover (Leibniz Institute for Applied Geosciences) at Grubenhagen for laboratory assistance.

\section{References}

Aguirre, E. \& Pasini, G., 1985. The Pliocene-Pleistocene boundary. Episodes 8 (2): 116-120

Bartz, J., 1974. Die Mächtigkeit des Quartärs im Oberrheingraben. In: Illies, J. H. \& Fuchs, K. (eds): Approaches to Taphrogenesis. Schweizerbart (Stuttgart): 78-87.

Becker-Haumann, R.A., 2001. The depositional history of the Bavarian Allgau area at the turn of the Tertiary/Quaternary, Northern Alpine Foreland, Germany - a set of paleogeological maps. Quaternary International 79: 55-64.

Boenigk, W., Von der Brelie, G., Brunnacker, K., Koci, A., Schlickum, W.R. \& Strauch, F., 1974. Zur Pliozän-Pleistozän-Grenze im Bereich der Ville (Niederrheinische Bucht). Newsletter Stratigraphy III (4): 219-241.

Boenigk, W. \& Frechen, M., 2005. The Pliocene and Quaternary fluvial archives of the Rhine system. Quaternary Science Reviews 25 (5-6): 550-574.

Butler, R.F., 1992. Paleomagnetism: magnetic domains to geological terranes. Blackwell (Boston): $319 \mathrm{pp}$

Cande, S.C. \& Kent, D.V., 1995. Revised calibration of the geomagnetic polarity timescale for the Late Cretaceous and Cenozoic. Journal of Geophysical Research B: Solid Earth 100: 6093-6095

Ellwanger, D., Gabriel, G., Hoselmann, C., Lämmermann-Barthel, J. \& Weidenfeller, M., 2005. The Heidelberg Drilling Project (Upper Rhine Graben, Germany). Quaternaire 16, (3): 191-199.

Evans, M.E. \& Heller, F., 2003. Environmental Magnetism - Principles and Applications of Enviromagnetics. Academic Press (San Diego): 299 pp.

Hagedorn, E.-M., 2004. Sedimentpetrographie und Lithofazies der Jungtertiären und Quartären Sedimente im Oberrheingebiet. Mathematisch-Naturwissenschaftliche Fakultät, Universität zu Köln, (Köln), 248 pp. http://kups.ub. uni-koeln.de/volltexte/2004/1253/

Hagedorn, E.-M. \& Boenigk, W., 2008. New evidences of the Pliocene and Quaternary sedimentary and fluvial history in the Upper Rhine Graben on basis of heavy mineral analyses. Netherlands Journal of Geosciences 87/1: 21-32. 
Han, J., Fyfe, W.S., Longstaffe, F.J., Palmer, H.C., Yan, F.H. \& Mai, X.S., 1997. Pliocene-Pleistocene climatic change recorded in fluviolacustrine sediments in central China. Palaeogeography, Palaeoclimatology, Palaeoecology 135: 27-39.

Harland, W.B., Armstrong, R.L., Cox, A.V., Craig, L.E., Smith, A.G. \& Smith, D.G., 1990. A geological time scale 1989. Cambridge University Press (Cambridge): $263 \mathrm{pp}$.

Haug, G.H. \& Tiedemann, R., 1998. Effect of the formation of the Isthmus of Panama on Atlantic 0cean thermohaline circulation. Nature 393: 673-676.

Heller, F. \& Liu, T.-S., 1982. Magnetostratigraphical dating of loess deposits in China. Nature 300: 431-433.

Horng, C.-S. \& Roberts, A.P., 2006. Authigenic or detrital origin of pyrrhotite in sediments?: Resolving a paleomagnetic conundrum. Earth and Planetary Science Letters 241, (3-4): 750-762.

Knipping, M., 2004. Pollenanalytische Untersuchungen an einem mittelpleistozänen Interglazial bei Mannheim. Tübinger Geowissenschaftliche Arbeiten, (Festschrift Bibus) D10: 199-217.

Knipping, M., 2008. Early and Middle Pleistocene pollen asssemblages of deep core drillings in the northern Upper Rhine Graben, Germany. Netherlands Journal of Geosciences 87/1: 51-65.

Litt, T., Ellwanger, D., Villinger, E. \& Wansa, S., 2002. The Quaternary rocks in the Stratigraphic Table of Germany 2002. Newsletters on Stratigraphy 41 (1-3): 385-399.

Mankinen, E.A. \& Dalrymple, G.B., 1979. Revised geomagnetic polarity time scale for the Interval 0 - 5 m.y. B.P. Journal of Geophysical Research 84 (B2): 615-626.

Rochette, $\boldsymbol{P}$., 1987. Metamorphic control of the magnetic mineralogy of black shales in the Swiss Alps: toward the use of 'magnetic isogrades'. Earth and Planetary Science Letters 84: 446-456.

Rolf, C., 2000. Das Kryogenmagnetometer im Magnetiklabor Grubenhagen. Geologisches Jahrbuch E52: 161-188.

Rowan, C.J. \& Roberts, A.P., 2006. Magnetite dissolution, diachronous greigite formation, and secondary magnetizations from pyrite oxidation: Unravelling complex magnetizations in Neogene marine sediments from New Zealand. Earth and Planetary Science Letters, 241 (1-2): 118-137.

Shackleton, N.J., Blackman, J., Zimmerman, H., Kent, D.V., Hall, M.A., Roberts, D.G., Schnitker, D., Baldauf, J.G., Desprairies, A., Homrighausen, R., Huddlestun, P., Keene, J.B., Kaltenback, A.J., Krumsiek, K.A.O., Morton, A.C., Murray, J.W. \& Westberg, S.J., 1984. Oxygen isotope calibration of the onset of ice-rafting and history of glaciation in the North Atlantic region. Nature 307: 620-623.

Snowball, I.F., 1997. Gyroremanent magnetization and the magnetic properties of greigite-bearing clays in southern Sweden. Geophysical Journal International 129: 624-636.

Snowball, I.F. \& Torii, M., 1999. Incidence and significance of magnetic iron sulphides in Quaternary sediments and soils. In: Maher, B.A. \& Thompson, R. (eds): Quaternary climates, environments and magnetism. Cambridge University Press (Cambridge): 199-230.

Strattner, M. \& Rolf, C., 1995. Magnetostratigraphische Untersuchungen an pleistozänen Deckschichtprofilen im bayerischen Alpenvorland. Geologica Bavarica, 99: 55-101.
Suc, J.P., Bertini, A., Leroy, S.A.G. \& Suballyova, D., 1997. Towards a lowering of the Pliocene/Pleistocene boundary to the Gauss/Matuyama Reversal. In: Partridge, T.C. (ed.): The Plio-Pleistocene boundary. Quaternary International 40: $37-42$.

Thompson, R. \& Oldfield, F., 1986. Environmental magnetism. Allen and Unwin (London): $227 \mathrm{pp}$.

Torii, M., Fukuma, K., Horng, C.-S. \& Lee, T.-Q., 1996. Magnetic discrimination of pyrrhotite- and greigite-bearing sediment samples. Geophysical Research Letters 23(14): 1813-1816.

Van Velzen, A.J. \& Zijderveld, J.D.A., 1992. A method to study alterations of magnetic minerals during thermal demagnetization applied to a fine-grained marine marl (Trubi formation, Sicily). Geophys. Journal International 110: 79-90.

Vasiliev, I., 2006. A new chronology for the Dacian Basin (Romania) Consequences for the kinematic and paleoenvironmental evolutuion of the Paratethys region. Geologica Ultraiectina 267: 193 pp, University Utrecht.

Von Dobeneck, T., 1993. Neue Ansätze zur Messung und Interpretation der magnetischen Hysterese von Tiefseesedimenten. Dissertation, Universität München, Verlag M. L. Leidorf (Buch am Erlbach): 190 pp.

Weidenfeller, M. \& Kärcher, T., 2008. Tectonic influence on fluvial preservation: Aspects of the architecture of Middle and Late Pleistocene sediments in the northern Upper Rhine Graben, Germany. Netherlands Journal of Geosciences 87/1: 33-40. 